\title{
PERBAIKAN PRESTASI BELAJAR MATEMATIKA SISWA MELALUI PENERAPAN MODEL PEMBELAJARAN KOOPERATIF TIPE TUTOR SEBAYA DI KELAS IV-A SD NEGERI 088 PANYABUNGAN
}

\author{
Suaidah \\ Guru SD Negeri 088 Panyabungan \\ Surel : suaidah@gmail.com
}

\begin{abstract}
Abstrak
Penelitian ini bertujuan untuk melihat peningkatan prestasi belajar siswa. Awal KBM dilakukan tes hasil belajar (Pretes), dengan data rata-rata 1,8. Kemudian dilanjutkan KBM, akhir KBM ke II dan KBM ke IV dilakukan tes hasil belajar formatif I dan formatif II dengan rata-rata hasil belajar masingmasing menunjukkan 2,3 dan 3,1. Melihat data tersebut ada perubahan dan perubahan tersebut akibat tindakan guru selama KBM pada siklus II dengan persentase ketuntasan klasikal 55,6\% dan $86 \%$.

Data aktivitas siswa menurut pengamatan pengamat pada siklus I antara lain membaca/menulis (38 \%), mengerjakan LKS (29\%), bertanya sesama teman (19\%), bertanya kepada guru (8\%), dan yang tidak relevan dengan KBM $(6 \%)$. Data aktivitas siswa menurut pengamatan pada siklus II antara lain membaca/menulis $(26,9 \%)$, mengerjakan LKS $(38,8 \%)$, bertanya sesama teman $(25,0 \%)$, bertanya kepada guru $(6,9 \%)$, dan yang tidak relevan dengan KBM $(2,5$ $\%)$.
\end{abstract}

Kata Kunci : Model, Kooperatif Tipe Tutor

\section{PENDAHULUAN}

Guru memiliki peranan yang sangat penting dalam menentukan kuantitas dan kualitas pengajaran yang dilaksanakan. Oleh karena itu guru harus memikirkan dan membuat perencanaan secara seksama dalam meningkatkan kesempatan belajar mengajar bagi siswanya dan kualistas mengajarnya. Guru seharusnya membantu siswa mengubah persepsi yang negatif terhadap belajar mengajar menjadi menyenangkan karena di dalam proses pembelajaran Matematika merupakan pelajaran yang paling penting dan disegani siswa dan tidak heran Matematika dianggap sebagai mata pelajaran yang sulit. Banyak siswa yang memiliki nilai rendah pada pembelajaran Matematika termasuk di sekolah tempat peneliti mengajar.

Berdasarkan pengalaman peneliti selama mengajar, peneliti jarang sekali menggunakan metode dan model pembelajaran yang bervariasi. Peneliti lebih sering menggunakan metode belajar konvensional yakni metode ceramah. Peneliti bertindak sebagai sumber informasi dan siswa menjadi objek belajar. Memang di akhir pembelajaran peneliti selalu memberikan soal sebagai evaluasi dari pembelajaran. Namun hasil yang peneliti peroleh tidak cukup 
memuaskan, hanya 10-20\% siswa yang benar-benar menguasai materi yang diajarkan guru dalam bentuk pengerjaan soal. Dilihat dari hasil ulangan harian siswa hal serupa juga terjadi. Hanya $45 \%$ siswa yang lulus kriteria ketuntasan minimum yang telah ditetapkan sekolah. Sedangkan sisanya harus mengikuti program remedial.

Kesiapan siswa hanya dapat dicapai berkat adanya usaha belajar dan latihan. Kesiapan disini meliputi sejumlah perkembangan sensorikmotorik, kebutuhan dan berbagai kemampuan serta cita-cita yang menyebabkan seseorang dapat menanggapi sesuatu dari pada yang lain.

Berdasarkan pengamatan peneliti terhadap proses belajar mengajar peneliti di kelas, peneliti jarang sekali menggunakan media belajar. Peneliti juga kurang dalam memotivasi siswa untuk lebih aktif belajar karena metode belajar yang peneliti terapkan kurang menyentuh kebutuhan siswa. Akibatnya motivasi, dan minat belajar siswa terhadap pembelajaran Matematika cukup rendah. Hal tersebut berimbas pada hasil belajar Matematika siswa yang menyebabkan hasil belajar siswa rendah.

Sebagai seorang tenaga pendidik yang merupakan ujung tombak kemajuan pendidikan nasional, maka peneliti merasa bahwa peneliti ikut bertanggung jawab dalam penyelesaian masalahmasalah yang timbul dalam dunia pendidikan, termasuk masalah yang

di hadapi oleh guru di sekolah seperti masalah yang peneliti hadapi. Bergabung dengan kelompok pelatihan keprofesionalan guru yang dibimbing oleh LPMP dan juga tutor dari Unimed peneliti mencoba untuk memperbaiki proses pembelajaran yang selama ini didalam kelas. Adapun materi yang di bahas dalam kelompok ini dalah upaya-upaya yang dapat dilakukan dalam meningkatkan kualitas mengajar guru. Salah satu upaya yang dapat dilakukan yakni pelaksanaan penelitian tindakan kelas dengan menerapkan model-model dan metode-metode pembelajaran yang inovatif. Melalui penelitian Tindakan Kelas ini diharapkan guru akan menemukan strategi belajar mengajar yang sesuai dan cocok dengan kondisi dan kebutuhan siswa yang akan mengakibatkan motivasi, minat, aktivitas dan hasil belajar siswa meningkat. Guru juga akan menjadi lebih terampil dalam mengajar karena mampu mengolah pembelajaran dengan baik, dan memberikan inovasi dalam proses pembelajarannya.

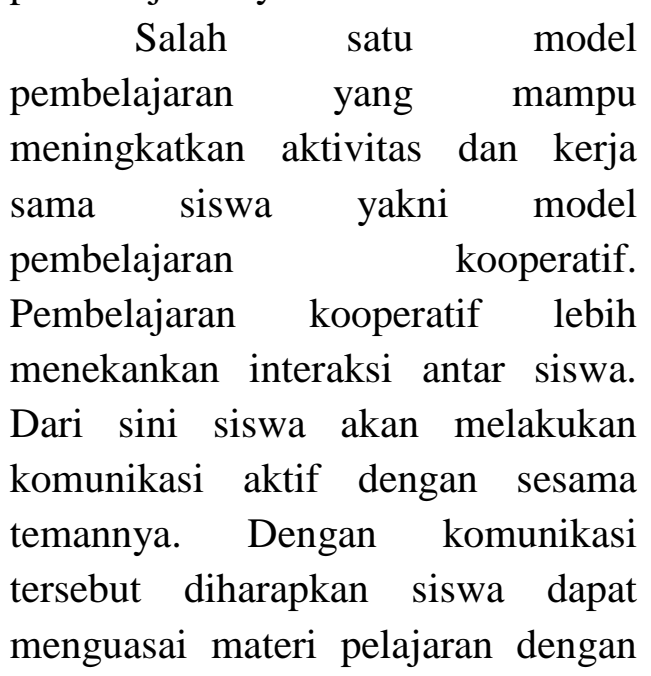


mudah karena "siswa lebih mudah memahami penjelasan dari kawannya dibanding penjelasan dari guru, karena taraf pengetahuan serta pemikiran mereka lebih sejalan dan sepadan.

Berdasarkan latar belakang masalah yang telah diuraikan, maka dapat diidentifikasi masalah yang relevan dengan penelitian ini, yakni :

a. Metode pembelajaran kurang bervariasi.

b. Guru lebih dominan menggunakan metode konvensional yakni metode ceramah.

c. Sering terjadi kegiatan yang tidak sesuai dengan kegiatan belajar mengajar (KBM) di dalam kelas, seperti siswa ribut, siswa mengantuk dan lain sebagainya.

d. Guru tidak menggunakan media dalam mengajar sehingga siswa sulit memahami materi yang diajarkan.

Bertitik tolak dari latar belakang diatas maka penulis merumuskan permasalahnnya sebagi berikut:

a. Apakah penerapan model pembelajaran kooperatif tipe tutor sebaya dapat meningkatkan aktivitas belajar Matematika siswa kelas IV-A SD Negeri 088 Panyabungan Tahun Pembelajaran 2014/2015?

b. Apakah penerapan model pembelajaran kooperatif tipe tutor sebaya dapat meningkatkan prestasi belajar

Matematika siswa kelas IV-A

SD Negeri 088 Panyabungan

Metode pemecahana masalah dalam penelitian ini yaitu dengan menerapkan model pembelajaran kooperatif tipe tutor sebaya selama kegiatan belajar mengajar. Dengan menerapkan model pembelajaran kooperatif tipe tutor sebaya ini diharapkan aktivitas yang bermuara pada prestasi belajar siswa dapat meningkat.

Penelitian ini bertujuan untuk:

a. Untuk mengetahui apakah penerapan model pembelajaran kooperatif tipe tutor sebaya dapat meningkatkan aktivitas belajar Matematika siswa kelas IV-A SD Negeri 088 Panyabungan Tahun Pembelajaran 2014/2015.

b. Untuk mengetahui apakah penerapan model pembelajaran kooperatif tipe tutor sebaya dapat meningkatkan prestasi belajar Matematika siswa kelas IV-A SD Negeri 088 Panyabungan Tahun Pelajaran 2014/2015.

Agar tidak terjadi salah persepsi terhadap judul penelitian ini, maka perlu didefinisikan halhal sebagai berikut:

a. Model pembelajaran kooperatif tipe tutor sebaya adalah model pembelajarn di mana seorang atau beberapa 
orang siswa yang ditunjuk dan ditugaskan untuk membentuk siswa yang mengalami kesulitan belajar, tutor tersebut diambil dari kelompok yang prestasinya lebih tinggi.

b. Prestasi Belajar adalah perubahan tingkah laku yang mencakup bidang kognitif, afektif dan psikomotor. Prestasi belajar merupakan kemampuan yang dimiliki siswa setelah ia mengalami pengalaman belajar.

c. Aktivitas belajar adalah kegiatan-kegiatan siswa yang menunjang keberhasilan belajar. Aktivitas belajar yang dimaksud adalah seluruh aktivitas siswa dalam proses belajar, mulai dari kegiatan fisik sampai kegiatan psikis.

\section{METODOLOGI PENELITIAN}

Lokasi penelitian ini dilakukan di SD Negeri 088 Panyabungan. Materi Pembelajaran yang diterapkan selama pengambilan data di kelas IV-A SD Negeri 088 Panyabungan adalah Operasi Hitung Perkalian dan Pembagian Penelitian ini dlaksanakan mulai bulan September 2014 sampai dengan Desember 2014.

Subjek dalam penelitian ini sebanyak I (satu) kelas yaitu kelas IV-A SD Negeri 088 Panyabungan sebanyak 36 orang. Adapun Kela IV-A dijadikan sebagai subjel penelitian karena peneliti merupakan guru kelas di kelas IV-A.

Penelitian ini menggunakan Penelitian Tindakan Kelas (PTK). PTK adalah suatu bentuk kajian yang bersifat reflektif oleh pelaku tindakan yang dilakukan untuk meningkatkan kemantapan rasional dari tindakan mereka dalam melaksanakan tugas, memperdalam pemahaman terhadap tindakan-tindakan yang dilakukan itu, serta memperbaiki kondisi dimana praktek pembelajaran tersebut dilakukan (dalam Mukhlis, 2000: 3).

Sesuai dengan jenis penelitian yang dipilih, yaitu penelitian tindakan, maka penelitian ini menggunakan model penelitian tindakan dari Kemmis dan Taggart (dalam Sugiarti, 1997:6), yaitu berbentuk spiral dari sklus yang satu ke siklus yang berikutnya. Setiap siklus meliputi planning (rencana), action (tindakan), observation (pengamatan), dan reflection (refleksi). Langkah pada siklus berikutnya adalah perencanaan yang sudah direvisi, tindakan, pengamatan, dan refleksi. Sebelum masuk pada Siklus I dilakukan tindakan pendahuluan yang berupa identifikasi permasalahan. Siklus spiral dari tahap-tahap penelitian tindakan kelas dapat dilihat pada gambar berikut.

\section{Gambar 3.1 Alur PTK}

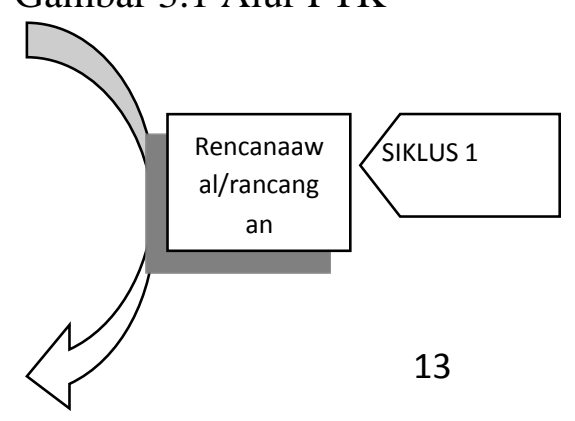




\section{Prosedur Penelitian}

Berdasarkan informasi yang penulis dapatkan, bahwa hasil belajar siswa pada mata pelajaran Matematika masih rendah, maka prosedur penelitian yang penulis rencanakan dalam menuntaskan hasil belajar tersebut adalah sebagai berikut :

\section{A. Siklus I}

Kegiatan pada Siklus I meliputi:

\section{Perencanaan Tindakan}

Pada tahap ini peneliti membuat kegiatan perencanaan meliputi:

a. Penyusunan rencana pelaksanaan pembelajaran dan lembar kegiatan siswa yang telah dibuat oleh guru. Selanjutnya diubah atau ditambah sesuai dengan Model pembelajaran Kooperatif tipe Tutor Sebaya.

b. Penyusunan instrumen penelitian berupa lembar observasi aktivitas siswa melalui penerapan Model pembelajaran Kooperatif tipe Tutor Sebaya dan tes pemahaman siswa tentang Operasi Hitung Perkalian dan Pembagian. c. Pelaksanaan Tindakan dan Observasi (Action and Observation)

Melaksanakan tindakan pembelajaran ke-1 dan ke-2 sesuai dengan RPP oleh peneliti sebagai guru di kelas IV-A SD Negeri 088 Panyabungan. Selama proses pembelajaran dilakukan observasi oleh observer (guru sejawat) untuk mengamati aktivitas siswa dan pengelolaan pembelajaran oleh guru.

d. Refleksi (Reflective)

Kegiatan refleksi dilakukan oleh peneliti berdasarkan hasil observasi dan evaluasi hasil pembelajaran Matematika dengan Model pembelajaran kooperatif tipe tutor sebaya. Dari hasil refleksi kemudian peneliti dengan dua orang pengamat teman sejawat untuk memperbaiki dan menguatkan rencana tindakan siklus II.

\section{B. Siklus II}

Kegiatan pada Siklus II meliputi:

a. Perencanaan Tindakan

Berdasarkan hasil refleksi terhadap proses pembelajaran pada siklus I maka pada siklus II disusun skenario Model pembelajaran kooperatif tipe tutor sebaya dengan revisi tindakan untuk memperbaiki proses. Peneliti berdiskusi secara kolaboratif dengan guru kelas lain dengan kegiatan perencanaan meliputi: 

a) Penyusunan rencana pelaksanaan pembelajaran dan lembar kegiatan siswa

e. Penyusunan instrumen penelitian berupa lembar observasi aktivitas siswa serta pengelolaan guru terhadap proses pembelajaran.

f. Pelaksanaan Tindakan dan Observasi (Action and

\section{Observation)}

Melaksanakan tindakan pembelajaran ke-3 dan ke-4 sesuai dengan RPP model pembelajaran kooperatif tipe tutor sebaya. Selama proses pembelajaran dilakukan observasi oleh observer (guru sejawat) untuk mengamati aktivitas siswa. Diakhir siklus II dilakukan pula tes hasil belajar.

g. Refleksi (Reflective)

Setelah kegiatan pembelajaran siklus II dilaksanakan, dilanjutkan dengan kegiatan refleksi oleh peneliti berkolaborasi guru mata pelajaran sejenis. Berdasarkan hasil observasi aktivitas siswa dalam pembelajaran dan ketuntasan hasil belajar siswa ditelaah

\section{Instrumen Penelitian}

Instrumen selama penelitian antara lain:

a. Instrumen Tes hasil Belajar Adapun kisi - kisi tesnya sebagai berikut :

\section{Tabel 3.1. Kisi-kisi test hasil belajar siswa}

\begin{tabular}{|l|c|c|c|}
\hline Indikator & $\begin{array}{c}\text { Bentuk } \\
\text { Soal }\end{array}$ & No. Soal & $\begin{array}{c}\text { Tingkat } \\
\text { Kognitif }\end{array}$ \\
\hline & essay & $1,2,3,4,5$ & C2,C2,C2, \\
& & & C2,C2 \\
\hline & essay & $6,7,8,9$, & C4,C4,C,4, \\
& & 10 & C4.C4 \\
Keterangan : & & \\
C1 : Pengetahuan \\
C2 : Pemahaman \\
C3 : Aplikasi \\
C4 : Analisis
\end{tabular}

b. Instrumen aktivitas belajar siswa Lembar aktivitas belajar siswa digunakan oleh pengamat. Pengamat adalah guru-guru teman sejawat peneliti yaitu Nasrun Lubis, S.Pd dan Nurainun Hutasuhut Waktu bekerja dalam kelompok peneliti/guru yang sedang melaksanakan kegiatan belajar mengajar (KBM) memberi isyarat pada ke dua pengamat, kelompok mana yang diamati oleh ke dua pengamat. Satu kali kegiatan belajar mengajar yang dilakukan oleh peneliti, maka ada dua kelompok yang diamati oleh pengamat.

Instrumen aktivitas belajar siswa terdiri dari 5 aktivitas antara lain; membaca, bekerja, bertanya sesama siswa, bertanya sama guru, dan yang tidak relevan denga KBM. Waktu siswa belajar sesuai dengan di RPP berkelompok selama 20 menit ditentukan oleh peneliti/guru maka ada 10 ceklis yang dilakukan oleh 
pengamat dalam lembar aktivitas belajar siswa.

Untuk menganalisis data-data tersebut di atas digunakan:

a. Teknik persentase, untuk menganalisis tingkat keberhasilan tes hasil belajar.

b. Teknik deskriptif, untuk menganalisis data-data persentase aktivitas.

Yang menjadi indikator keberhasilan guru mengajar digunakan Kurikulum 2013 atau kriteria ketuntasan minimal (KKM) di sekolah untuk mata pelajaran Matematika adalah 2,5 / (70). Jika nilai $\geq 70$ siswa tuntas secara individu. Jika nilai $\geq 70$ diperoleh $\geq$ $85 \%$ dikatakan tuntas secara klasikal/tuntas kelas.

\section{HASIL PENELITIAN DAN PEMBAHASAN}

Pembelajaran menggunakan model pembelajaran kooperatif tutor sebaya dengan menitik beratkan pada siswa. Model pembelajaran ini mengharapkan siswa akan lebih aktif karena siswa akan belajar dari temannya sendiri, selain itu metode pembelajaran ini mengharapkan siswa akan lebih cepat tanggap terhadap materi karena mereka belajar dari temannya sendiri.

Penelitian ini dilaksanakan di kelas IV-A SD Negeri 088 Panyabungan, Tahun Pelajaran 2014/2015 dengan jumlah siswa 36 orang. Penelitian ini dilakukan pada mata pelajaran Matematika dengan materi operasi hitung perkalian dan pembagian. Sebelum KBM Siklus I berlangsung telah tersusun perangkat-perangkat pembelajaran yang dibutuhkan dalam menerapkan model, diantaranya RPP, LKS, instrument tes hasil belajar dan instrument observasi aktivitas. Perangkat untuk tindakan pada Siklus II dipersiapkan setelah melakukan refleksi pada akhir Siklus

\section{Hasil Belajar}

Sebelum kegiatan belajar dimulai sesuai dengan perumusan awal melalui diskusi dengan pembimbing dan pendamping, maka peneliti/guru melakukan tes hasil belajar (Pretes), hasil analisisnya dapat dilihat pada Tabel 4.1. Hasil belajar dalam penelitian ini meliputi aspek kognitif, Ringkasan hasil belajar kognitif siswa sebelum dan sesudah diterapkan model pembelajan tutor sebaya dapat diuraikan sebagai berikut:

\section{a. Data Pretes (Data Awal)}

Data pretes diuraikan dalam Tabel berikut:

Tabel 4.1 Distribusi Hasil Pretes Kelas IV-A

\begin{tabular}{|c|c|c|}
\hline Nilai & Frekuensi & Rata-rata \\
\hline
\end{tabular}




\begin{tabular}{|c|c|}
\hline 0,4 & 1 \\
\hline 0,8 & 2 \\
\hline 1,2 & 3 \\
\hline 1,6 & 10 \\
\hline 2,0 & 16 \\
\hline 2,4 & 4 \\
\hline Jumlah & 36 \\
\hline
\end{tabular}

Merujuk pada Tabel 4.1, nilai terendah untuk pretes adalah 0,4 dan tertinggi adalah 2,4 dengan nilai ratarata kelas adalah 1,8. Dengan demikian tidak ada siswa yang mencapai nilai ketuntasan minimal yaitu 2,5. Berdasarkan data hasil pretes, dapat dinyatakan bahwa siswa belum mempersiapkan diri sebelumnya dirumah. Bentuk grafik batang dapat dilihat pada Gambar 4.1

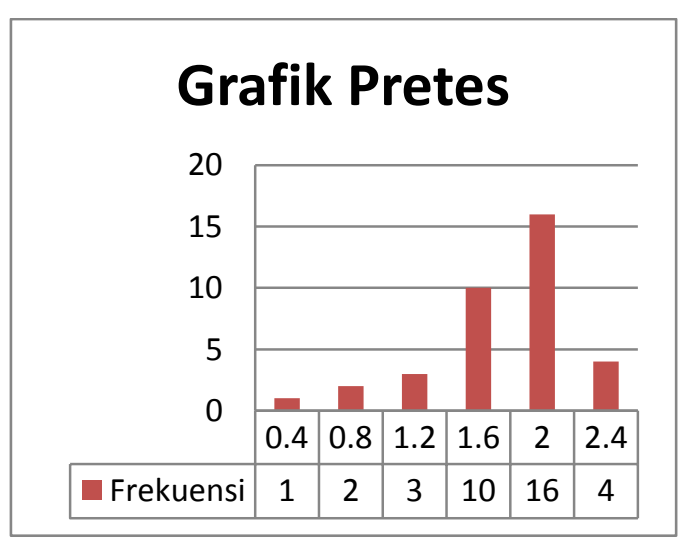

\section{Gambar .4.1 Grafik Data Hasil Pretes}

\section{b. Data Hasil belajar (Formatif)}

\section{Siklus I}

Hal-hal yang dilakukan dalam perencanaan adalah : a. Menyiapkan Silabus dan RPP

b. Menyiapkan Materi Pelajaran

c. Menyiapkan Lembar Kegiatan Siswa (LKS 1 dan LKS 2)

d. Menyiapkan soal tes hasil belajar (Formatif I)

e. Menyiapkan lembar pengamatan untuk pengelolaan kelas serta aktivitas siswa dan guru.

\section{Pelaksanaan dan observasi}

Penelitian pada Putaran I dilaksanakan pada :

- Hari / Tanggal: Senin, 20 Oktober 2014, dan Kamis 23 Oktober 2014

- Les : ke 2 dan 1

- Materi Pokok Bahasan: Operasi hitung pembagian dan perkalian

- Pengelola Kelas (Guru): Hj. Suaidah, S.Pd

- Pengamat Nasrun Lubis dan Nurainun Hutasuhut

\section{Rekaman kegiatan pembelajaran pada siklus}

\section{Pertemuan 1}

Pada tanggal 20 Oktober 2014 tepatnya les 1 dan 2, Guru Matematika, memasuki kelas IV-A. Menjelang pintu masuk siswa-siswi terlihat sedang sibuk, ada yang menulis, ada yang asyik bercerita, ada juga siswa yang menempati kursi temannya. Ketika guru melangkah di pintu masuk siswa-siswi tersentak diam dan siswa yang berada diluar ruang bergegas menuju ruangan kelas.

Guru memberi salam , 
"Assalamualaikum dan selamat pagi".

Siswa-siswi menjawab serentak,

"walaikum salam dan selamat pagi Bu?".

Ada yang masih di luar? Tanya guru. "Ada

2 orang Bu, Jawab ketua kelas. Setelah itu, guru menyuruh siswa untuk mengumpulkan sampah yang berserakan di depan kelas dan merapikan meja kursi tempat belajar siswa. Pada saat itu 2 orang siswa yag terlambat mengetok pintu dan guru mengijinknnya masuk ke dalam kelas.

Sebelum pelajaran dimulai peneliti mengajak para siswa untuh terlebih dahulu berdoa, setelah berdoa peneliti mengabsen siswa dan ternyata semua siswa hadir. Sebelum peneliti memulai pelajaran kembali peneliti meminta anak-anak untuk meluruskan meja dan memperbaiki cara duduk masing-masing.

Baik, hari ini kita lanjutkan materi kita yaitu "Pembagian". Pada saat pelajaran berlangsung Reno Rosihan Anwar yang duduk dibangku dua tidak bisa diam dia selalu gelisah, sesekali dia menoleh kebelakang dan menyapa temannya yang duduk dibelakangnya, melihat kejadian itu peneliti bertanya "apa yang kalian bicarakan? Amir Hamsah yang duduk dibelakangnya menjawab spontan. 'Reno ketinggalan uang jajan bu “ jawabnya".

Sebelum kita masuk ke pelajaran pembagian, siapa yang bisa mengerjakan soal ini?. Lalu guru menuliskan soal pengurangan dan penambahan di depan kelas. Aulia rama angkat tangan dan berkata, "saya Bu". Kemudian guru menyahut sambil memberikan spidol kepada Aulia, "Silahkan Aulia", kata ibu guru. Lalu Aulia menuliskan jawaban yang benar di papan tulis dan guru mengajak siswa untuk memberikan tepuk tangan kepada Aulia. Setelah itu Guru menuliskan judul di papan tulis, kemudian menjelaskan langkah-langkah dalam pembagian dalam hitungan. Setelah menjelaskna materi, guru memberikan beberapa contoh dan kemudian guru membagi siswa dalam kelompok dan membagi LKS untuk dikerjakan. Pada saat diskusi, guru berkeliling kelas untuk melihat aktivitas diskusi siswa dan kolabolator yang sudah dipilih pada saat perencanaan melakukan pengamatan terhadap siswa.

Selesai kerja kelompok, Guru minta Kamil lubis untuk mengerjakan soal nomor 1 yang ada di LKS, Sahilah nomor 2, Nursakinah nomor 3, Fitri nomor 4, dan April nomor 5. Selesai mereka mengerjakan soal, guru meminta teman kelompok yang lain untuk memberikan pendapat. Setelah selesai mengerjakan soal, Guru dan siswa menarik kesimpulan cara mengerjakan soal pembagian yang benar. Setelah itu Guru memberi PR. Bel berbunyi, guru mengucapkan salam "Assalamualikum dan selamat pagi" sambil berjalan ke luar. Siswa serentak menjawab "walaikum salam dan selamat pagi Bu".

\section{Pertemuan 2}

Kamis 23 Oktober 2014 seperti biasa sebelum pelajaran dimulai anak-anak membaca doa yang dipimpin ketua kelas. Pada kesempatan ini kita masih belajar tentang perkalian dan pembagian agar lebih semangat peneliti memberikan apersepsi dengan cara melemparkan beberapa perkalian dengan catatan siapa yang lebih dulu tunjuk tangan dia yang menjawab.

Selanjutnya peneliti meminta anak-anak membentuk kelompok menjadi 8 kelompok, pembagian kelompok sesuai dengan pembagian kelompok yang telah ditentukan sebelumnya. Saat kerja kelompok siswa yang lebih pandai membantu untuk mengajari temannya yang kurang mampu

didalam kelompoknya. Peneliti membagikan LKS pada masing-masing kelompok, siswa diberikan waktu selama 20 menit untuk menyelesaikan permasalahan yang ada pada lembar LKS, saat diskusi dalam kelompok peneliti bertindak sebagai motivator sedangkan 2 orang observer mengamati aktivitas belajar siswa. Setelah diskusi kemudian peneliti meminta supaya kelompok 18 3 tampil kedepan untuk mempersentasikan hasil diskusinya. Kelompok 3 dengan kurang semangat mengambil posisi didepan kelas. 
Setelah data pretes di analisis, maka peneliti melakukan tes hasil belajar siswa (Formatif I). Hasil analisisnya dapat dilihat pada Tabel 4.2 .

Tabel 4.2 Distribusi Hasil Formatif I

\begin{tabular}{|c|c|c|}
\hline Nilai & Frekuensi & Rata-rata \\
\hline 0,8 & 8 & \\
\hline 1,6 & 7 & \multirow{2}{*}{2,3} \\
\hline 2,4 & 1 & \\
\hline 3,2 & 20 & \\
\hline Jumlah & 36 & \\
\hline
\end{tabular}

Hasil analisis pada Tabel 4.2 tersebut, nilai terendah Formatif I adalah 0,8 dan tertinggi adalah 2,3 dengan 16 orang nilainya masih dibawah kriteria ketuntasan minimum, ketuntasan klasikal atau ketuntasan dalam kelas adalah adalah sebesar $55,55 \%$. Nilai ini berada di bawah kriteria ketuntasan minimum, sehingga dapat dikatakan KBM
Siklus I kurang berhasil memberikan ketuntasan belajar dalam kelas. Nilai rata-rata kelas adalah 2,3. Data hasil Formatif I ini dapat disajikan kembali dalam grafik histogram (Gambar 4.2) .

\section{Refleksi}

Setelah melakukan proses pembelajaran pada siklus I dengan penerapan model tutor sebaya, ada beberapa tindakan yang dilakukan oleh guru dan siswa sehingga proses belajar mengajar belum mencapai hal-hal yang diharapkan. Tindakantindakan tersebut antara lain adalah:

a. Siswa mula-mula kurang bisa menerima pembagian kelompok secara heterogen yang memiliki kemampuan akademis tinggi, sedang dan rendah karena mereka sudah terbiasa dengan temanteman dalam kelompok sebelumnya yang tidak heterogen, karena kelompok sebelumnya dibentuk berdasarkan pilihan siswa sendiri terdiri dari siswasiswa yang akrab atau teman sepermainan.

b. Siswa belum terbiasa dengan model yang diterapkan oleh guru karena siswa biasa dengan pembelajaran yang berpusat pada guru sehingga siswa merasa bingung mengakibatkan suasana kelas agak ramai. 
c. Media yang digunakan oleh guru tidak ada sehingga siswa susah untuk mengaplikasikan dalam kehidupan sehari-hari.

Pada kondisi pembelajaran yang diharapkan bersifat kondusif, yang melibatkan siswa secara aktif dalam mengamati, atau berlatih menggunakan objek konkrit disertai dengan diskusi diharapkan siswa dapat bangkit sendiri untuk berfikir, untuk menganalisis data, untuk menjelaskan ide, untuk bertanya, untuk berdiskusi, dan untuk menulis apa yang dipikirkan sehingga memberi kesempatan siswa untuk mengkonstruksikan pengetahuannya sendiri. Dimana hal tersebut (konstruktivisme) merupakan landasan berfikir (filosofi) pendekatan kontekstual (Nurhadi,2003:33).

Dengan adanya tindakan yang tidak mendukung proses belajar mengajar ini, guru perlu melakukan yang namanya refisi. Untuk melakukan refisi, guru berkoordinasi dengan pembimbing, teman sejawat, kolabolator dan pendamping. Dari hasil diskusi antara guru dengan pembimbing, teman sejawat, dan pendamping, ada beberapa tindakan yang harus dilakukan yaitu:

a. Guru mempersiapkan media yang dapat menarik perhatian siswa seperti kue, buah, dan lidi.

b. Sebelum masuk ke dalam materi, guru memberikan motivasi belajar dan

kegunaan materi yang diajarkan sehingga siswa akan merasa bahwa belajar itu penting.

c. Guru mengarahkan siswa untuk lebih aktif dalam berdiskusi dan memberikan pendapat kepada temannya sendiri.

\section{Siklus II \\ Rencana}

Hal-hal yang dilakukan dalam perencanaan adalah :

a. Menyiapkan Silabus dan RPP

b. Menyiapkan Materi Pelajaran

c. Menyiapkan Lembar

Kegiatan Siswa (LKS 3 dan LKS 4)

d. Menyiapkan soal tes hasil belajar (Formatif II)

e. Menyiapkan lembar pengamatan untuk pengelolaan kelas serta aktivitas siswa dan guru.

\section{Pelaksanaan dan observasi}

Penelitian pada Putaran II dilaksanakan pada :

- Hari / Tanggal : Senin, 27 Oktober 2014 dan Kamis, 30 Oktober 2014

- Les : ke 1 dan ke 2

- Materi Pokok Bahasan: Operasi hitung pembagian dan perkalian

- Pengelola Kelas (Guru): $\mathrm{Hj}$. Suaidah, S.Pd

- Pengamat : Nasrun Lubis, S.Pd dan Nurainun Hutasuhut. 
Selain mempersiapkan perangkat pembelajaran yang akan dilaksanakan pada siklus II ini, guru juga mempersiapkan alat peraga dan media yang akan digunakan pada saat pembelajaran. Dalam proses pembelajaran siklus II ini guru akan melakukan perbaikan-perbaikan dari siklus I dengan harapan dapat meningkatkan prestasi dan aktivitas siswa. Adapun rekaman pembelajaran yang terlaksana pada siklus II ini adalah:

\section{Pertemuan 3}

Pada tanggal 27 Oktober 2014 tepatnya les 1 dan 2, Guru Matematika, memasuki kelas IV-A. Menjelang pintu masuk siswa-siswi terlihat sedang sibuk mengerjakan sesuatu. Pada saat guru memasuki ruang kelas, ada beberapa siswa yang tidak menyadarinya sehingga mereka terkejut ketika melihat guru sudah ada di meja guru. Guru memberi salam , “Assalmualaikum anak-anak". Siswa-siswi menjawab serentak, "Walaikum salam Bu?". Ada yang masih di luar? Tanya guru. "tidak ada Bu, Jawab ketua kelas. Setelah itu, guru menyuruh siswa untuk mengumpulkan tugas yang diberikan oleh guru pada pertemuan sebelumnya. Setelah itu guru memanggil Sakinah ke depan kelas. Sakinah ketakutan dan malu-malu maju ke ke depan kelas. Namun guru meyakinkah bahwa tidak ada yang salah. Sampai di depan, guru memberikan kapur kepada sakinah dan menyuruh untuk mengerjakan soal pekerjaan rumah di papan tulis.

Baik, hari ini kita lanjutkan materi kita yaitu "Pembagian dan perkalian". Setelah itu Guru menuliskan judul di papan tulis, kemudian menjelaskan langkahlangkah dalam pembagian dalam hitungan. Setelah menjelaskna materi, guru memberikan beberapa contoh dengan menggunakan media pembelajaran yaitu kue dan buah. Kemudian guru membagi siswa dalam kelompok dan membagi LKS untuk dikerjakan. Pemimpin setiap kelompok adalah siswa yang paling tinggi nilai pretesnya sehingga ia dapat membimbing kawan-kawannya. Pada saat diskusi, guru berkeliling kelas untuk melihat aktivitas diskusi siswa dan kolabolator yang sudah dipilih pada saat perencanaan melakukan pengamatan terhadap siswa.

Selesai kerja kelompok, Guru minta Ahmad untuk mengerjakan soal nomor 1 yang ada di LKS, Febri nomor 2, Robiatul nomor 3, Riski nomor 4, dan Fatika nomor 5. Selesai mereka mengerjakan soal, guru meminta teman kelompok yang lain untuk memberikan pendapat. Setelah selesai mengerjakan soal, Guru dan siswa menarik kesimpulan cara mengerjakan soal pembagian yang benar. Setelah itu Guru memberi PR. Bel berbunyi, guru mengucapkan salam "Assalamualaikum" sambil berjalan ke luar. Siswa serentak menjawab "walaikum salam Bu”.

\section{Pertemuan 4}

Kamis pada tanggal 30 Oktober 2014, Guru sebagai peneliti, memasuki kelas IV-A. Menjelang pintu masuk peneliti langsung mengucapkan salam dengan kalimat "assalamualaikum anakanak! dan selamat apagi" siswa menjawab walaikum salam bu, pagi bu". Peneliti mengajak siswa untuk semuanya berdiri lalu memerintahkan ketua kelas untuk memimpin doa. Selanjutnya peneliti mengabsen siswa dengan cara memanggil nama-nama siswa berdasarkan abjad pada buku absen, dan

Baik, hari ini kita lanjutkan materi kita yaitu "Pembagian dan perkalian". Setelah itu Guru menuliskan judul di papan tulis, kemudian menjelaskan langkahlangkah dalam pembagian dalam hitungan. Setelah menjelaskna materi, guru memberikan beberapa contoh dengan 1 menggunakan media pembelajaran yaitu kue dan buahKemudian guru membagi siswa dalam kelompok dan membagi LKS 
pertanyaan, dan berdiskusi dengan anggota kelompok. Siswa sudah dapat menerima pembagian kelompok secara heterogen, masingmasing individu dalam kelompok sudah menyadari akan tanggungjawabnya sebagai anggota kelompok sehingga kerjasama antara anggota keloimpok berjalan dengan baik dan tugas-tugas yang diberikan guru dapat dengan mudah diselesaikan oleh masing-masing kelompok.

Setelah data formatif II terkumpul maka data tersebut dianalisis. Dalam melanjutkan kegiatan belajar mengajar berikutnya atau disebut Siklus II perlu ada perubahan pembelajaran baik media, dan alat bahan yang sesuai dengan materi pembelajarannya. Hasil analisis formatif II dapat dilihat pada:

Tabel 4.3 Distribusi Hasil Formatif II

\section{Perbaikan Tindakan}

Pada siklus II, guru
melaksanakan
pembelajaran untuk menyelesaikan
permasalahan-permasalahan yang
ada pada Siklus I. Upaya yang
dilakukan adalah dengan
menyediakan media pembelajaran,
berdiskusi dan bekerjasama dengan
teman satu kelompoknya dalam
mengerjakan tugas.
Pada Siklus II sudah tidak
lagi ditemukan kendala-kendala
berarti. Siswa-siswa banyak
mengajukan pertanyaan, menjawab

\begin{tabular}{|c|c|c|}
\hline Nilai & Frekuensi & Rata-rata \\
\hline 1,6 & 2 & \multirow{2}{*}{3} \\
\hline 2,4 & 3 & \multirow{2}{*}{3,1} \\
\hline 3,2 & 27 & \\
\hline 4 & 4 & \\
\hline Jumlah & 36 & \\
\hline
\end{tabular}

Merujuk pada Tabel 4.3, nilai terendah untuk formatif II adalah 1,6 dan tertinggi adalah dengan 5 orang mendapat nilai dibawah kriteria 
ketuntasan atau ketuntasan klasikal adalah sebesar $86,11 \%$. Nilai ini berada di atas kriteria keberhasilan sehingga dapat dikatakan KBM siklus II telah berhasil memberi ketuntasan belajar dalam kelas. Nilai rata-rata kelas adalah 3,1. Data hasil formatif II ini dapat disajikan kembali dalam grafik histogram sebagai berikut:

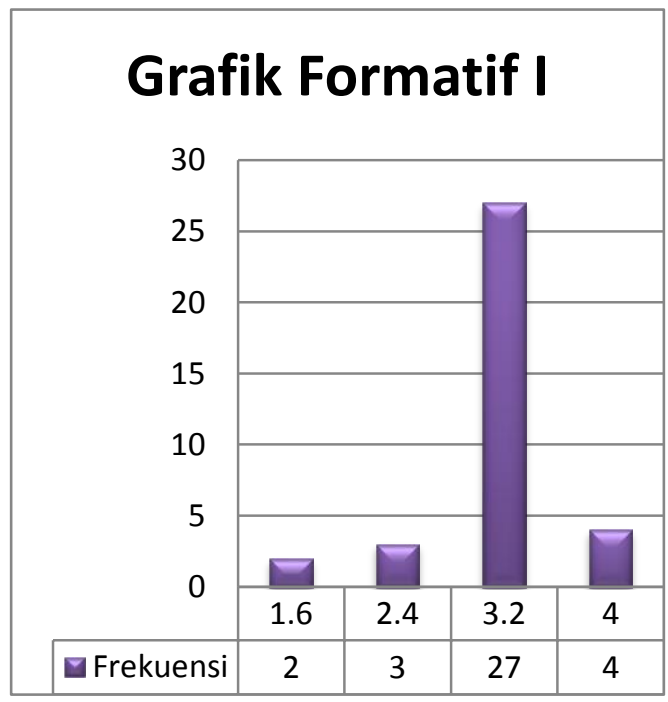

\section{Gambar .4.3 Grafik data hasil formatif II}

Dengan adanya perbaikan tindakan atas pembelajaran pada siklus I, Penerapan model pembelajaran tutor sebaya yang dilakukan di kelas IV-A dengan mata pelajaran Matematika, materi ajar operasi hitung pembagian dan perkalian dapat meningkatkan hasil belajar siswa. Hal ini merujuk pada tabel-tabel hasil tes yang telah dipaparkan sebelumnya, dapat dilihat nilai dari rata-rata tes atau nilai pretes siswa sebelum diterapakan model pembelajaran tutor sebaya adalah 1,8 dan setelah diterapkan model pembelajaran tutur sebaya dapat meningkat hasil belajar siswa menjadi 2,3 pada siklus I dan 3,1 pada siklus II. Ketuntasan belajar secara klasikal juga mengalami peningkatan, sebelum dilakukan model pembelajaran tutor sebaya tingkat ketuntasan belajar siswa adalah $0 \%$ dan pada siklus I siswa yang tuntas hanya 20 orang siswa dari 36 siswa, dengan persentase ketuntasan adalah 55,55\%. Pada siklus II, jumlah siwa yang mencapai ketuntasan minimal ada sebanyak 31 orang dari 36 siswa dengan jumlah persentase kelulusan adalah $86,11 \%$.

Tabel 4.4. Rekapitulasi hasil tes siswa sebelum penelitian, akhir siklus I dan II

\begin{tabular}{|l|c|c|c|}
\hline Hasil Tes & Data Awal & Siklus I & Siklus II \\
\hline Nilai Tertinggi & 2,4 & 3,2 & 4,0 \\
\hline Nilai terendah & 0,4 & 0,8 & 1,6 \\
\hline Rata-rata nilai tes & 1,8 & 2,3 & 3,1 \\
\hline Ketuntasan klasikal & $0 \%$ & $55,55 \%$ & $86,11 \%$ \\
\hline
\end{tabular}

Peningkatan hasil tes siswa dapat dilihat melalui tabel dan histogram berikut: 


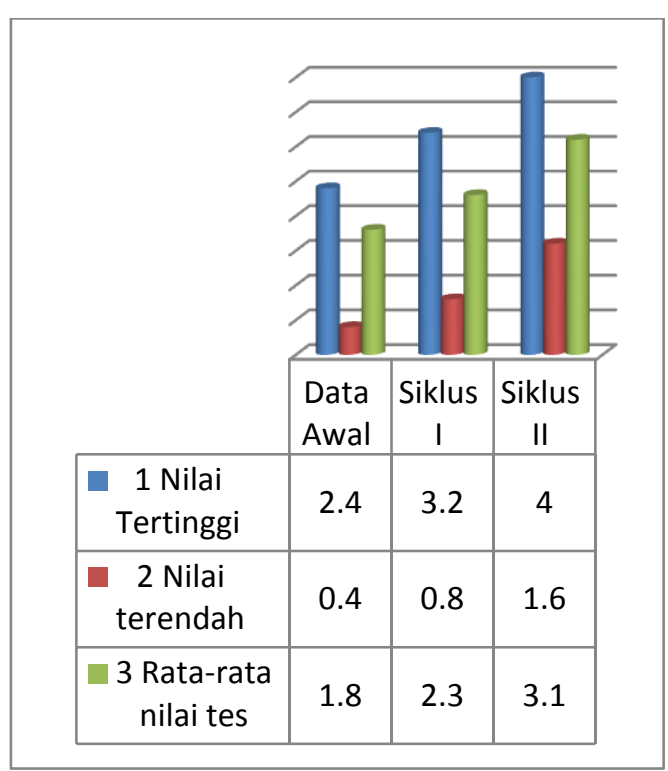

Gambar 4.4 Grafik Hasil Belajar Kognitif

\section{Data Aktivitas belajar}

Selama pelaksanaan pembelajaran pertemuan 1 dan pertemuan 2 peneliti berkolaborasi dengan dua orang teman sejawat yang disebut sebagai pengamat, begitu juga dengan pembelajaran siklus II pada pertemuan 3 dan pertemuan 4. Dua orang pengamat ini untuk mengamati atau memantau aktivitas siswa selama berdiskusi dalam kelompoknya. Pengamatan aktivitas siswa dilakukan dengan menceklis setiap dua menit sekali pada lembar aktivitas siswa yang telah disiapkan peneliti sebelumnya.

Penilaian aktivitas diperoleh dari lembar observasi aktivitas. Pengamatan dilakukan oleh dua pengamat selama 20 menit kerja kelompok dalam setiap KBM atau 40 menit dalam satu Siklus. Dengan pengamatan setiap 2 menit, maka nilai maksimum yang mungkin teramati untuk satu kategori aktivitas selama 40 menit adalah 20 kali. Pada Siklus I rata-rata aktivitas I yakni menulis dan membaca memperoleh persentase $38,0 \%$. Sebagian besar siswa belum memahami kegiatan apa yang dikerjakanya sehingga aktivitas individual dalam diskusi yang pasif masih mendominasi. Pada Siklus II aktivitas ini mengalami penurunan persentase menjadi $26,9 \%$ yang menunjukkan bahwa siswa sudah mulai terbiasa dengan penerapan model dan tindakan yang dilakukan di Siklus II berfungsi cukup efektif untuk menekan aktivitas diskusi pasif ini. Aktivitas yang mengalami perbaikan adalah persentase siswa dalam mengerjakan LKS yaitu $29,0 \%$ pada siklus I mengalami peningkatan menjadi $38,8 \%$. Penskoran dilakukan dan dijabarkan dalam data berupa Tabel aktivitas oleh pengamat I untuk Siklus I dan Siklus II sebagai berikut: 
Tabel 4.5 Skor aktivitas belajar siswa

\begin{tabular}{|c|c|c|c|}
\hline \multicolumn{4}{|c|}{ Siklus I } \\
\hline No & Aktivitas & Skor & Persentase \\
\hline 1 & Menulis/membaca & 19 & $38,0 \%$ \\
\hline 2 & Mengerjakan LKS & 15 & $29,0 \%$ \\
\hline 3 & Bertanya pada teman & 10 & $19,0 \%$ \\
\hline 4 & Bertanya pada guru & 4 & $8,0 \%$ \\
\hline 5 & $\begin{array}{l}\text { Yang tidak relevan dengan } \\
\text { KBM }\end{array}$ & 3 & $6,0 \%$ \\
\hline \multicolumn{4}{|c|}{ Siklus II } \\
\hline No & Aktivitas & Skor & Persentase \\
\hline 1 & Menulis/membaca & 11 & $26,9 \%$ \\
\hline 2 & Mengerjakan LKS & 16 & $38,8 \%$ \\
\hline 3 & Bertanya pada teman & 10 & $25,0 \%$ \\
\hline 4 & Bertanya pada guru & 3 & $6,9 \%$ \\
\hline 5 & $\begin{array}{l}\text { Yang tidak relevan dengan } \\
\text { KBM }\end{array}$ & 1 & $2,5 \%$ \\
\hline
\end{tabular}

Data pada Tabel 4.5 dapat di sajikan dalam diagram batang atau histogram sesuai Gambar 4.5 berikut:

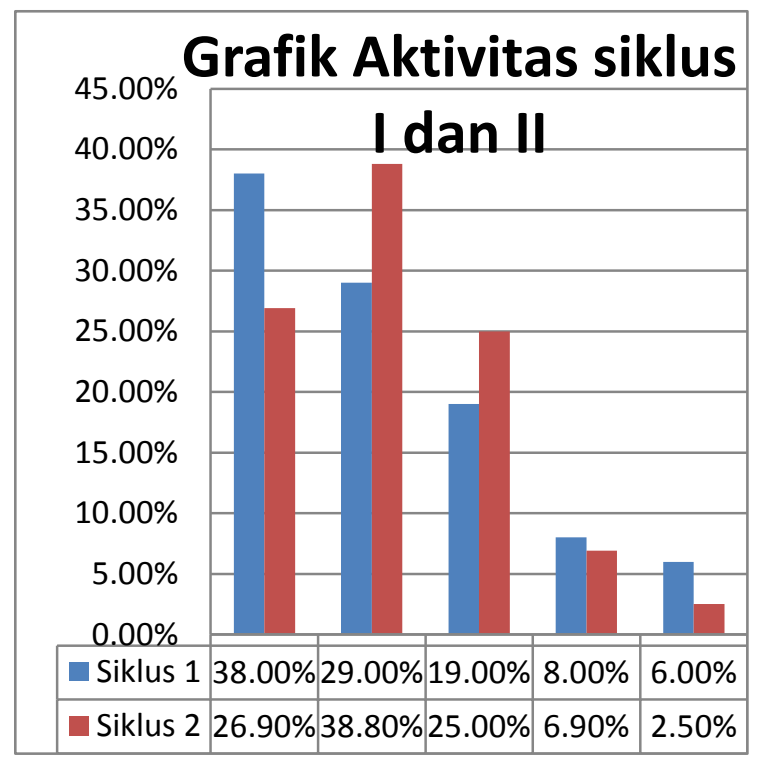

Keterangan:

1. Menulis,menbaca

2. Mengerjakan

3. Bertanya pada teman

4. Bertanya pada guru

5. Yang tidak relevan

\section{Gambar 4.5 Grafik aktivitas siswa Siklus I dan Siklus II}

Merujuk pada Grafik 4.5, dapat ditemukan bahwa aktivitas mengerjakan dalam diskusi yang pada Siklus I hanya mencapai $29 \%$ mengisyaratkan KBM Siklus I belum efektif mengarahkan siswa bekerja dalam diskusi yang baru pada Siklus II tindakan yang diberikan mulai membuat siswa beradaptasi belajar dalam diskusi aktif dan aktivitas mengerjakan naik menjadi $38,8 \%$ pada Siklus ini.

Aktivitas bertanya pada teman dalam diskusi pada Siklus I hanya mencapai $19 \%$ dan pada Siklus II naik menjadi 25,0\%. Sementara aktivitas bertanya pada guru pada Siklus I sebesar $8 \%$ dan turun pada Siklus II menjadi 6,9\% yang berarti ketergantungan siswa terhadap bimbingan guru saat bekerja dalam kelompok pada Siklus II berkurang.

Aktivitas-aktivitas yang tidak relevan pada Siklus I sebesar 6\%, menunjukkan kondisi kelas kurang kondusif. Beberapa siswa mengobrol dalam, diskusi dan mengganggu teman yang lain. Rekaman data aktivitas juga menunjukkan beberapa siswa melakukan kegiatan tidak relevan ini hampir sepanjang waktu 
pengamatan. Pada Siklus II kondisi kelas mulai kondusif, di sepanjang pengamaatan hampir tidak ada siswa tercatat melakukan aktivitas tidak relevan, dengan skor aktivitas sebesar $2,5 \%$.

\section{Pembahasan}

Merujuk pada Tabel 4.4 nilai rata-rata siswa sebelum diberikan pembelajaran melalui model pembelajaran tutor sebaya yaitu berupa nilai pretes sebesar 1,8 dengan ketuntasan klasikal $0 \%$. Setelah diadakan pembelajaran dengan model pembelajaran tutor sebaya pada materi pokok operasi hitung pembagian dan perkalian nilai siswa meningkat. Pada akhir Siklus I diperoleh rata-rata nilai formatif I siswa mencapai 2,3 dengan ketuntasan klasikal sebesar 55,55\%. Karena nilai ini tidak lebih besar dari 85\% sebagai acuan ketuntasan klasikal, berarti kegiatan belajar mengajar Siklus I belum mampu memberikan ketuntasan belajar dalam kelas.

Merujuk pada Tabel 4.4 tersebut di akhir Siklus II ketuntasan belajar secara klasikal mencapai $86,11 \%$. Dengan demikian hasil belajar kognitif siswa pada Siklus II sudah memenuhi indikator yang telah ditetapkan dalam penelitian yaitu sekurang-kurangnya $\quad 85 \%$ dari keseluruhan siswa yang ada di kelas tersebut memperoleh nilai diatas 2,5 atau mencapai ketuntasan $86,11 \%$. Hal ini berarti kegiatan belajar mengajar Siklus II yakni menerapkan model pembelajaran tutor sebaya dengan memberikan tindakan perbaikan telah memberikan ketuntasan belajar dalam kelas. Namun demikian ketuntasan klasikal yang belum sempurna tersebut mengindikasikan bahwa terdapat siswa yang mendapat nilai tidak tuntas pada akhir Siklus II yaitu 5 siswa dari 36 orang.

Merujuk pada Grafik 4.5, dapat ditemukan bahwa aktivitas mengerjakan dalam diskusi yang pada Siklus I hanya mencapai 29\% mengisyaratkan KBM Siklus I belum efektif mengarahkan siswa bekerja dalam diskusi yang baru pada Siklus II tindakan yang diberikan mulai membuat siswa beradaptasi belajar dalam diskusi aktif dan aktivitas mengerjakan naik menjadi $38,8 \%$ pada Siklus ini.

Aktivitas bertanya pada teman dalam diskusi pada Siklus I hanya mencapai $19 \%$ dan pada Siklus II naik menjadi 25,0\%. Sementara aktivitas bertanya pada guru pada Siklus I sebesar $8 \%$ dan turun pada Siklus II menjadi 6,9\% yang berarti ketergantungan siswa terhadap bimbingan guru saat bekerja dalam kelompok pada Siklus II berkurang.

Aktivitas-aktivitas yang tidak relevan pada Siklus I sebesar 6\%, menunjukkan kondisi kelas kurang kondusif. Beberapa siswa mengobrol dalam, diskusi dan mengganggu teman yang lain. Rekaman data aktivitas juga menunjukkan beberapa siswa melakukan kegiatan tidak relevan ini hampir sepanjang waktu pengamatan. Pada Siklus II kondisi 
kelas mulai kondusif, di sepanjang pengamaatan hamper tidak ada siswa tercatat melakukan aktivitas tidak relevan, dengan skor aktivitas sebesar $2,5 \%$.

\section{Tabel 4.6 Rekapitulasi ketuntasan belajar klasikal tiap Siklus}

\begin{tabular}{|c|c|c|}
\hline Aspek Penilaian & $\begin{array}{c}\text { Siklus } \\
\text { I }\end{array}$ & $\begin{array}{c}\text { Siklus } \\
\text { II }\end{array}$ \\
\hline Hasil Belajar Kognitif & $\begin{array}{c}55,55 \\
\%\end{array}$ & $\begin{array}{c}86,11 \\
\%\end{array}$ \\
\hline $\begin{array}{ll}\text { Aktivitas } & \text { Belajar } \\
\text { - } & \text { Membaca/menulis } \\
\text { - } & \text { Mengerjakan } \\
\text { - } & \text { Bertanya pada } \\
& \text { teman } \\
\text { - } & \text { Bertanya pada } \\
& \text { guru } \\
\text { - Tidak relevan } & \\
& \text { dengan KBM }\end{array}$ & $\begin{array}{c}38 \% \\
29 \% \\
19 \% \\
8 \% \\
6 \%\end{array}$ & $\begin{array}{c}26,9 \% \\
38,8 \% \\
25,0 \% \\
6,9 \% \\
2,5 \%\end{array}$ \\
\hline
\end{tabular}

Merujuk pada data Pretes, Formatif I dan Formatif II diketahui bahwa nilai rata-rata dan ketuntasan kelas mengalami peningkatan, namun pada Siklus I peningkatan ini belum mencapai kriteria minimum yang ditetapkan. Belum tercapainya indikator yang telah ditetapkan dalam penelitian ini dikarenakan masih ditemukannya permasalahanpermasalahan yang ada pada Siklus I. Permasalahan-permasalahan tersebut antara lain:

a. Siswa mula-mula kurang bisa menerima pembagian kelompok secara heterogen yang memiliki kemampuan akademis tinggi, sedang dan rendah karena mereka sudah terbiasa dengan teman-teman dalam kelompok sebelumnya yang tidak heterogen, karena kelompok sebelumnya dibentuk berdasarkan pilihan siswa sendiri terdiri dari siswa-siswa yang akrab atau teman sepermainan.

b. Siswa belum terbiasa dengan model yang diterapkan oleh guru karena siswa biasa dengan pembelajaran yang berpusat pada guru sehingga siswa merasa bingung mengakibatkan suasana kelas agak ramai.

c. Media yang digunakan oleh guru tidak ada sehingga siswa susah untuk mengaplikasikan dalam kehidupan sehari-hari. Sehingga pada Siklus II, guru melaksanakan perbaikan pembelajaran untuk menyelesaikan permasalahan-permasalahan yang ada pada Siklus I. Upaya yang dilakukan adalah:

a. Guru mempersiapkan media yang dapat menarik perhatian siswa seperti kue, buah, dan lidi.

b. Sebelum masuk ke dalam materi, guru memberikan motivasi belajar dan kegunaan materi yang diajarkan sehingga siswa akan merasa bahwa belajar itu penting.

c. Guru mengarahkan siswa untuk lebih aktif dalam berdiskusi dan memberikan pendapat kepada temannya sendiri.

Pada Siklus II sudah tidak lagi ditemukan kendala-kendala berarti, karena siswa sudah dapat 
menyesuaikan dengan pembelajaran menggunakan model pembelajaran tutor sebaya. Siswa-siswa banyak mengajukan pertanyaan, dan berdiskusi dengan anggota kelompok. Siswa sudah dapat menerima pembagian kelompok secara heterogen, masing-masing individu dalam kelompok sudah menyadari akan tanggungjawabnya sebagai anggota kelompok sehingga kerjasama antara anggota keloimpok berjalan dengan baik dan tugas-tugas yang diberikan guru dapat dengan mudah diselesaikan oleh masingmasing kelompok.

Hasil belajar pada Siklus II mengalami peningkatan ketuntasan klasikal yang melebihi indikator keberhasilan. Dengan adanya peningkatan tersebut menunjukkan bahwa model pembelajaran tutor sebaya yang mengkaitkan antara materi pelajaran dengan situasi dunia nyata siswa melalui komponenkomponen utama dalam pembelajarannya dapat meningkatkan pemahaman siswa terhadap operasi hitung pembagian dan perkalian.

\section{SIMPULAN DAN SARAN Simpulan}

Adapun kesimpulan dari upaya meningkatkan prestasi belajar dan aktivitas belajar siswa melalui model pembelajaran tutor sebaya selama kegiatan belajar mengajar pada mata pelajaran matematika dengan materi pokok operasi hitung pembagi dan perkalian di kelas IV-A
SD Negeri 088 Panyabungan dengan jumlah siswa 36 orang sebagai berikut:

a. Data aktivitas siswa menurut pengamatan observer pada Siklus I antara lain membaca/menulis (38\%), mengerjakan (29\%) $)$ bertanya sesama teman (19\%), bertanya kepada guru (8\%), dan yang tidak relevan dengan KBM (6\%).

b. Data aktivitas siswa menurut pengamatan observer pada Siklus II antara lain membaca/menulis $(26,9 \%)$, mengerjakan (38,8\%), bertanya sesama teman (25,0\%), bertanya kepada guru $(6,9 \%)$, dan yang tidak relevan dengan KBM $(2,5 \%)$.

c. Hasil belajar siswa pada materi pokok oprasi hitung pembagian dan perkalian dengan menerapkan model pembelajaran tutor sebaya pada Siklus I mencapai ratarata 2,3 dengan ketuntasan klasikal 55,55\% dan Siklus II mencapai 3,1 dengan ketuntasan klasikal 86,11\%.

Dengan demikian terjadi peningkatan hasil belajar siswa dan peningkatan pada aktivitas belajar siswa membuktikan bahwa penerapan model pembelajaran tutor sebaya pada mata pelajaran matematika dengan materi pokok operasi hitung pembagian dan perkalian di kelas IV-A SD Negeri 088 Panyabungan. 


\section{Saran}

Setelah melakukan kegiatan belajar mengajar selama empat kali atau disebut dua Siklus maka perlu saran agar pengguna atau yang memanfaatkan model pembelajaran tutor sebaya di sekolah benar-benar bermanfaat sesuai dengan tujuan penelitian.

a. Selama kerja kelompok perlu aturan-aturan di informasikan kepada siswa sesuai dengan tujuan berkelompok, agar tujuan berkelompok dapat tercapai dan dapat dilihat pada tes hasil belajar secara individu.

b. Perlu motivasi diberikan pada awal pertemuan agar selama bekerja dalam kelompok aktivitas siswa sangat baik.

c. Sikap siswa perlu diperhatikan dan direkap selama KBM dan direfleksikan baik hasil kelompok belajar, aktivitas siswa selama bekerja dan sikapnya selama bekerja.

DAFTAR RUJUKAN

BNSP. 2006. Petenjuk Teknis Pengembangan Silabus Mata Pelajaran Teknologi Informasi dan Komunikasi. Debniknas.

Degeng, I N. S. 1988. Ilmu Pengajaran:Taksonomi variabel. Jakarta : Depdikbud Dirjen Dikti P2LPTK.

Maryono, Dwi. (2007). Buku Theory and Application of ICT 3. PT Tiga Serangkai Pustaka Mandiri. Jakarta.
Mulyanto A. 2009. Sistem Informasi Konsep \& Aplikasi. Pustaka pelajar Yokjakarta

Prosiding. Berbagai Makalah Sistem Informasi dalam $\mathrm{KN}$ 2009.

SMK Swadayat. 2007. Penerapan Metode Tutor Sebaya dalam upaya mengoptimalkan pemebelajaran mata pelajaran KKPI. Alamat Web :http://smkswadayatm g.wordpress.com/xmlr pc.php.

Syah, Muhibbin. 2006. Psikologi Pendidikan dengan Pendekatan Baru, Bandung : PT Rasda karya.

Tuhuserta Sawali. 2007. Diskusi Kelompok

Terbimbing Model Tutor Sebaya. Alamat Web :http://sawali.infoltuto r sebayalDiskusi Kelompok Terbimbing Model Tutor Sebaya Catatan Sawali Tuhusetya.htm 